\title{
KARYOTYPE STUDY IN THE SURF CLAM MESODESMA DONACIUM LAMARCK, 1818 (BIVALVIA: VENEROIDA: MESODESMATIDAE)
}

\author{
ESTUDIO CARIOTIPICO EN LA MACHA MESODESMA DONACIUM \\ LAMARCK, 1818 (BIVALVIA: VENEROIDA: MESODESMATIDAE)
}

\author{
Gabriel Amar ${ }^{1 *}$, Claudio Palma Rojas², Elisabeth von Brand ${ }^{3}$ \\ \& Pedro Jara-Seguel ${ }^{4}$ \\ ${ }^{1}$ Universidad Pedro de Valdivia, Facultad de Ciencias de la Salud, Cuatro Esquinas 060, La Serena, Chile. \\ ${ }^{2}$ Universidad de La Serena, Departamento de Biología, Casilla 599, La Serena, Chile. \\ ${ }^{3}$ Universidad Católica del Norte, Departamento de Biología Marina, Casilla 117, Coquimbo, Chile. \\ ${ }^{4}$ Universidad Católica de Temuco, Escuela de Ciencias Ambientales, Casilla 15-D, Temuco, Chile. \\ *Corresponding author, e-mail: gabamar@gmail.com
}

\begin{abstract}
Mesodesma donacium is a marine clam distributed from Sechura Bay $\left(5^{\circ} \mathrm{S}\right)$ in northern Perú to Chiloé Island $\left(43^{\circ} \mathrm{S}\right)$ in southern Chile. Due to the commercial importance of this species, their populations have been reduced in the later years. In this work the karyotype morphology of $M$. donacium is described for the first time, to be additional to taxonomical, ecological, morphological, and reproductive antecedents previously documented for the species. $M$. donacium shows a diploid karyotype $2 \mathrm{n}=38$ with one metacentric, fifteen submetacentric and three subtelocentric chromosome pairs. The total haploid set length was $42.4 \mu \mathrm{m}$, and the mean chromosome size was $2.2 \mu \mathrm{m}$. $M$. donacium showed similitude in chromosome number with other species of the Veneroida order, but differences were found in morphology and size of the chromosomes. The cytogenetic relationships between M. donacium and other species of Veneroida is also discussed.
\end{abstract}

Keywords: Veneroida, Mesodesmatidae, Cytogenetic relationshipt, chromosomes, karyotype morphology.

\section{RESUMEN}

Mesodesma donacium es un almeja distribuida desde Sechura Bay $\left(5^{\circ} \mathrm{S}\right)$ en el Norte de Perú hasta la isla de Chiloé $\left(43^{\circ} \mathrm{S}\right)$ en el sur de Chile. Debido a la importancia económica de esta especie, su población ha sido reducida en los últimos años. En este trabajo se describe por primera vez la morfología cariotípica de $M$. donacium, como antecedentes adicionales taxonómicos, ecológicos, morfológicos y reproductivos descritos previamente para la especie. M. donacium muestra un cariotipo diploide $2 \mathrm{n}=38$ con un par metacéntrico, quince submetacéntricos y tres pares cromosómicos subtelocéntricos. La longitud total del set haploide fue de $42,4 \mu \mathrm{m}$ y el tamaño cromosómico medio fue de 2,2 $\mu \mathrm{m}$. M. donacium mostró una similitud en el número cromosómico con otras especies del Orden Veneroida, sin embargo fueron encontradas diferencias en tamaño y morfología de los cromosomas. Se discuten las relaciones citogenéticas entre M. donacium y otras especies de Veneroida.

Palabras claves: Veneroida, Mesodesmatidae, Relaciones citogenéticas, cromosomas, cariotipo. 


\section{INTRODUCTION}

Mesodesmatidae is represented in Chile by Mesodesma donacium Lamarck 1818 andErvilia producta Odhner 1922. M. donacium has an extensive latitudinal distribution from Sechura Bay in northern Perú to Chiloé Island in southern Chile $\left(5^{\circ} \mathrm{S}-43^{\circ} \mathrm{S}\right)$ (Osorio \& Bahamonde 1970), whereas Ervilia producta Odhner 1922 has restricted distribution in the coasts of the Juan Fernández archipelago (Osorio \& Bahamonde 1970).

In Chile, $M$. donacium is the most known species of the family due to its commercial importance, but in the later years their populations have been reduced due to superextraction. At present, the biological information for M. donacium is scarce where only ecology, fishery, morphology, taxonomy, and reproduction have been the most studied field (Osorio \& Bahamonde 1968; Osorio 1979; Brown \& Guerra 1979; Peredo et al. 1987; Fuentes 1988; Ortiz \& Stotz 1996, 2003; Joo \& Dupré 2002). Besides, preliminary genetic studies in $M$. donacium have included isozyme analysis for five populations from northern, central and southern Chile (Urriola \& von Brand 2003), but the gap on genome information is still prevalent for their populations. Genome data are crucial to elaborate programs trends to the conservation of those species of commercial importance whose populations have been reduced by super-extraction. Thus, the chromosome studies may be a basis to understood detail on genome organization in the clam $M$. donacium, such as has been previously documented for other bivalve species of the Veneroida order (see a revision in Méndez et al. 2001 and ThiriotQuiévreux 2002).

In order to known the first cytogenetic antecedent for M. donacium, in this work the karyotype morphology is described and its cytogenetic relationship with other species of the order Veneroida is also discussed.

\section{MATERIALS AND METHODS}

Adult specimens of Mesodesma donacium were obtained from Tongoy and Coquimbo Bays $\left(30^{\circ} \mathrm{S}\right)$, in Central Chile. Gametes were obtained by stripping the gonads by making superficial scalpel incisions near the foot and removing gametes by pipette. Samples from each individual were examined by light microscopy to determine the sex of gametes obtained, as the gonads do not demonstrate sexual dimorphism. Gametes from 3 to 5 mature females for in vitro fertilization were suspended in $400 \mathrm{ml}$ of filtered seawater at room temperature $\left(\sim 20^{\circ} \mathrm{C}\right)$. Spermatozoa from two to three mature males were separately collected into $100 \mathrm{ml}$ of the same water above mentioned and were then mixed with the eggs. The fertilization and early development stages ere monitored by light microscopy. When the embryos reached the 8 to 16 cell stage they were treated with $0.05 \%$ Colchicine in seawater diluted to $70 \%$ of its original salinity using distilled water for $90 \mathrm{~min}$. For fixation and extraction of vitellum the embryos were treated with ethanol-chloroform-acetic acid (6:3:1 v/v) for $24 \mathrm{~h}$, and then preserved in methanol-glacial acetic acid $(3: 1 \mathrm{v} / \mathrm{v})$ until require.

Embryos staining were carried out using the Feulgen reaction as modified by Navarrete et al. (1983). Squash preparations were made of the embryos and coverslips were raised using freezing with $\mathrm{CO}_{2}$. The embryos were then counterstained using $2 \%$ Giemsa in $\mathrm{pH} 6.8$ phosphate buffer.

In microphotographs of ten metaphase plates the short arms (SA) and long arms (LA) were measured and the relative length of each chromosome-arm (expressed as percentage of the total haploid set length) was calculated. Besides, total haploid set length (THL in $\mu \mathrm{m}$ ) and mean chromosome size (CZ in $\mu \mathrm{m})$ were determined for $M$. donacium. The values for mean relative length for SA and LA ( \pm confidence interval at 95\%) were displayed in a Karyo-Idiogram (Spotorno 1985). The karyotype was constructed according to decreasing chromosome length and chromosome morphology on the basis of the categories proposed by Levan et al.(1964).

\section{RESULTS}

The gametes obtained by stripping were viable, and in vitro fertilization occurred with no adverse complications. A modal chromosome number $2 \mathrm{n}=38$ was obtained for $M$. donacium when 100 metaphase plates were counted. Besides, four meiotic cells were observed which showed 19 bivalents (data not shown). The karyotype of Mesodesma donacium is composed of one metacentric, fifteen submetacentric and three subtelocentric chromosome pairs (Figs. 1 and 2). Secondary constrictions were not observed in the chromosomes. The pair 1 ( $\mathrm{LR}=7.59 \%$ ) is the only metacentric chromosome within the karyotype.

The total haploid set length for $M$. donacium was $42.2 \mu \mathrm{m}$ and the mean chromosome size was $2.2 \pm 0.53$ $\mu \mathrm{m}$. Quantitative karyotype data are shown in Table I. 


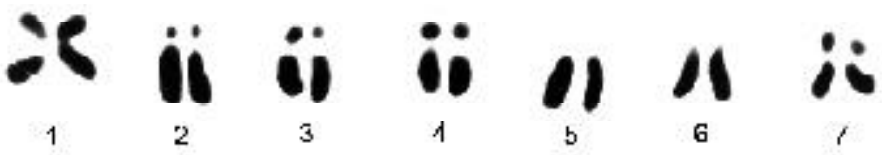

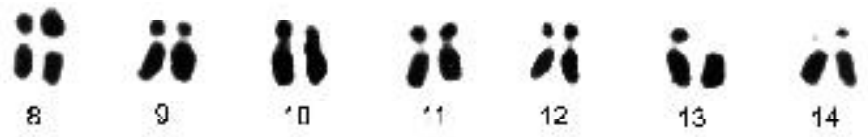

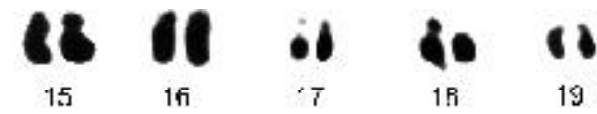

5 um

FIGURE 1: Karyotype of Mesodesma donacium, $2 \mathrm{n}=38(1 \mathrm{M}+15 \mathrm{SM}+3 \mathrm{ST})$.

FIgURA 1: Cariotipo de Mesodesma donacium, $2 \mathrm{n}=38(1 \mathrm{M}+15 \mathrm{SM}+3 \mathrm{ST})$.

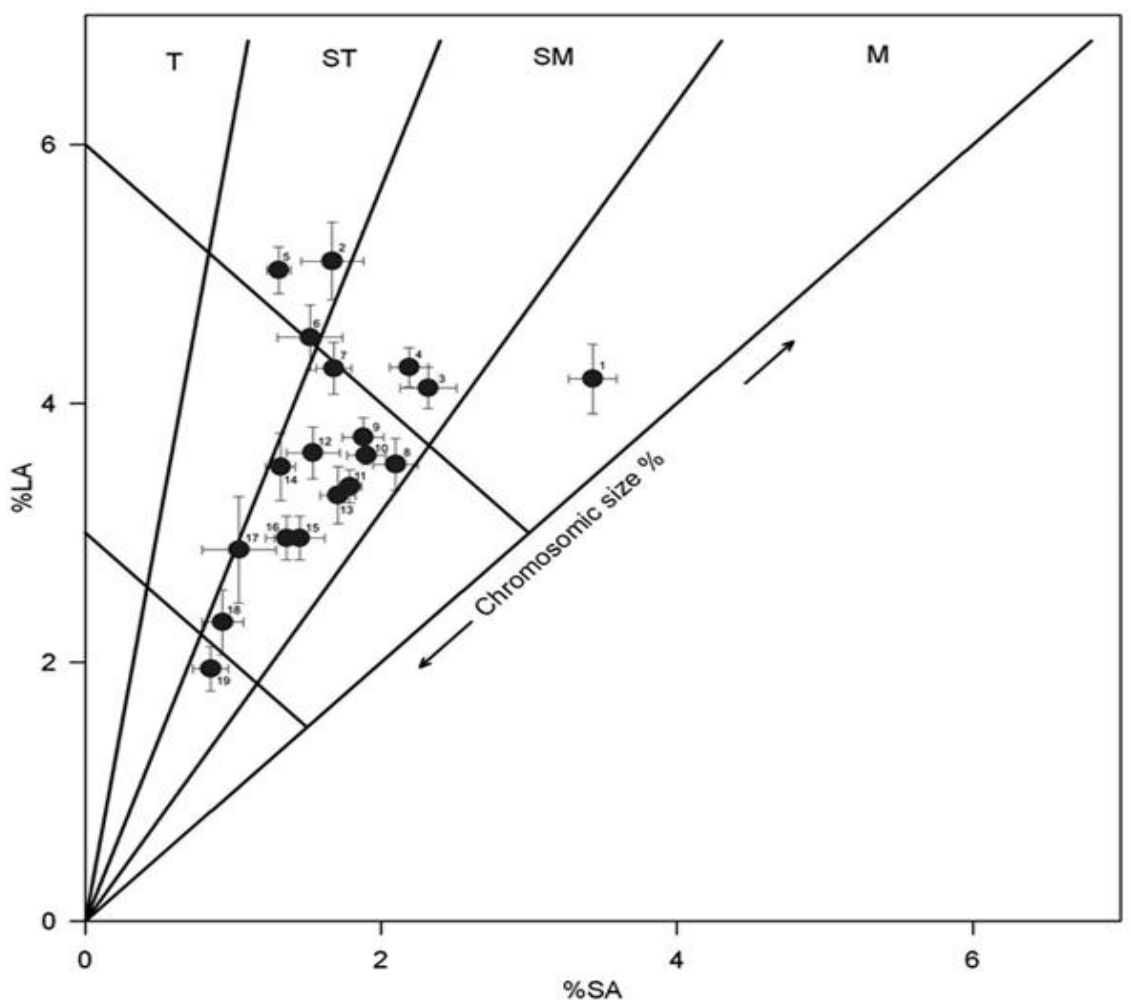

FIGURE 2: Karyo-Idiogram that represents of the relative length of the short arm (SA) and the long arm (LA) of each chromosome pairs of Mesodesma donacium, $\mathrm{n}=19 . \mathrm{M}=$ metacentric, $\mathrm{SM}=$ submetacentric, $\mathrm{ST}=$ subtelocentric, $\mathrm{T}=$ telocentric. Spots represent centromere position and the bars represent 95\% confidence intervals for SA and LA.

FIGURA 2: Cario-Idiograma que representa la longitud relativa del brazo corto (SA) y del brazo largo(LA) de cada par cromosómico en Mesodesma donacium, $\mathrm{n}=19 . \mathrm{M}=$ metacéntrico, $\mathrm{SM}=$ submetacéntrico, $\mathrm{ST}=$ subtelocéntrico, $\mathrm{T}=$ telocéntrico. Puntos negros representan la posición del centrómero y las barras representan el 95\% de intervalo confianza para SA y LA. 
TABLE I: Chromosome measurements on Mesodesma donacium. SA, length of the short arm; LA, length of the long arm; C, total chromosome length; s.d., standard deviation; CI, 95\% confidence interval.

TABLA I: Medidas cromosómicas en Mesodesma donacium. SA, longitud del brazo corto; LA, longitud del brazo largo; C, longitud cromosómica total; s.d., desviación estándar; CI, 95\% intervalo de confianza.

\begin{tabular}{|c|c|c|c|c|c|c|c|c|}
\hline \multirow[b]{2}{*}{$\begin{array}{l}\text { Chr. } \\
\text { pair }\end{array}$} & \multicolumn{3}{|c|}{ Absolute arm lengths $(\mu \mathrm{m})$} & \multicolumn{5}{|c|}{ Relative arm lengths (\%) } \\
\hline & $\mathrm{SA} \pm$ s.d. & $\mathrm{LA} \pm$ s.d. & $\mathrm{C} \pm$ s.d. & $\mathrm{SA} \pm \mathrm{s} . \mathrm{d}$ & CI & $\mathrm{LA} \pm$ s.d. & CI & Type \\
\hline 1 & $1.42 \pm 0.29$ & $1.73 \pm 0.37$ & $3.15 \pm 0.64$ & $3.40 \pm 0.24$ & 0.16 & $4.19 \pm 0.42$ & 0.27 & M \\
\hline 2 & $0.75 \pm 0.19$ & $2.07 \pm 0.56$ & $2.82 \pm 0.60$ & $1.67 \pm 0.32$ & 0.21 & $5.10 \pm 0.46$ & 0.30 & ST \\
\hline 3 & $0.94 \pm 0.35$ & $1.84 \pm 0.40$ & $2.78 \pm 0.51$ & $2.32 \pm 0.29$ & 0.19 & $4.12 \pm 0.24$ & 0.16 & SM \\
\hline 4 & $0.89 \pm 0.39$ & $1.85 \pm 0.44$ & $2.74 \pm 0.56$ & $2.19 \pm 0.20$ & 0.13 & $4.28 \pm 0.23$ & 0.15 & SM \\
\hline 5 & $0.62 \pm 0.23$ & $2.03 \pm 0.45$ & $2.65 \pm 0.50$ & $1.31 \pm 0.13$ & 0.08 & $5.03 \pm 0.27$ & 0.18 & ST \\
\hline 6 & $0.64 \pm 0.23$ & $1.89 \pm 0.40$ & $2.53 \pm 0.46$ & $1.52 \pm 0.33$ & 0.22 & $4.51 \pm 0.39$ & 0.25 & ST \\
\hline 7 & $0.78 \pm 0.24$ & $1.63 \pm 0.36$ & $2.42 \pm 0.50$ & $1.68 \pm 0.19$ & 0.12 & $4.27 \pm 0.30$ & 0.20 & SM \\
\hline 8 & $0.88 \pm 0.36$ & $1.55 \pm 0.24$ & $2.43 \pm 0.44$ & $2.10 \pm 0.23$ & 0.15 & $3.53 \pm 0.31$ & 0.20 & SM \\
\hline 9 & $0.74 \pm 0.18$ & $1.64 \pm 0.31$ & $2.38 \pm 0.40$ & $1.88 \pm 0.22$ & 0.14 & $3.74 \pm 0.22$ & 0.15 & SM \\
\hline 10 & $0.68 \pm 0.20$ & $1.63 \pm 0.40$ & $2.31 \pm 0.38$ & $1.90 \pm 0.20$ & 0.13 & $3.60 \pm 0.10$ & 0.07 & SM \\
\hline 11 & $0.75 \pm 0.26$ & $1.51 \pm 0.22$ & $2.25 \pm 0.42$ & $1.54 \pm 0.27$ & 0.18 & $3.62 \pm 0.30$ & 0.20 & SM \\
\hline 12 & $0.78 \pm 0.12$ & $1.46 \pm 0.34$ & $2.24 \pm 0.43$ & $1.79 \pm 0.11$ & 0.08 & $3.36 \pm 0.17$ & 0.13 & SM \\
\hline 13 & $0.72 \pm 0.11$ & $1.39 \pm 0.45$ & $2.11 \pm 0.48$ & $1.71 \pm 0.18$ & 0.12 & $3.29 \pm 0.33$ & 0.22 & SM \\
\hline 14 & $0.58 \pm 0.13$ & $1.40 \pm 0.45$ & $1.98 \pm 0.45$ & $1.32 \pm 0.16$ & 0.10 & $3.51 \pm 0.39$ & 0.26 & SM \\
\hline 15 & $0.62 \pm 0.19$ & $1.33 \pm 0.39$ & $1.95 \pm 0.47$ & $1.45 \pm 0.22$ & 0.17 & $2.96 \pm 0.22$ & 0.17 & SM \\
\hline 16 & $0.53 \pm 0.14$ & $1.36 \pm 0.25$ & $1.90 \pm 0.31$ & $1.36 \pm 0.16$ & 0.14 & $2.96 \pm 0.20$ & 0.17 & SM \\
\hline 17 & $0.54 \pm 0.35$ & $1.06 \pm 0.22$ & $1.60 \pm 0.25$ & $1.04 \pm 0.30$ & 0.25 & $2.87 \pm 0.48$ & 0.41 & SM \\
\hline 18 & $0.40 \pm 0.13$ & $0.92 \pm 0.22$ & $1.32 \pm 0.33$ & $0.93 \pm 0.21$ & 0.14 & $2.31 \pm 0.38$ & 0.25 & SM \\
\hline 19 & $0.39+0.09$ & $0.86+0.23$ & $1.26 \pm 0.30$ & $0.85 \pm 0.12$ & 0.12 & $1.95 \pm 0.17$ & 0.17 & SM \\
\hline
\end{tabular}

\section{DISCUSSION}

Within the bivalve class, the most studied karyotype characters are $2 \mathrm{n}$ number, chromosome morphology and chromosome size. In this work, those three characters were determined in the karyotype of $M$. donacium.

The chromosome number of $M$. donacium counted here is coincident with the most frequent number $2 \mathrm{n}$ $=38$ so far documented for other 16 species of Veneroida (Méndez et al. 2001, Thiriot-Quiévreux 2002, Jara-Seguel 2007). Besides, meiotic cells with 19 bivalents corroborate that 2 number. These data suggest conservationism in the chromosome number within the order Veneroida on the basis of the nine families world-wide studied.

The most actualized cytogenetic revisions so far documented for Veneroida have discussed the polymorphism in chromosome morphology and chromosome size present among the species. Following that tendency, the karyotype morphology described here for $M$. donacium is different to the karyotypes described for other species of the order, where intra-specific variation has also been observed in several species of the families Cardiidae, Tellinidae and Veneridae (Méndez et al. 2001, Thiriot-Quiévreux 2002). Furthermore, the total haploid set length (THL $=42.4 \mu \mathrm{m})$ and mean chromosome size $(\mathrm{CZ}=2.2 \mu \mathrm{m})$ described here for $M$. donacium are lower to the values described for other species of the order with 38 chromosomes, such as Donax trunculus (THL = 114.28 $\mu \mathrm{m}, \mathrm{CZ}=6.01 \mu \mathrm{m}$ ) (Donacidae) (Cornet \& Soulard 1990a), Macoma balthica $(\mathrm{THL}=84.58 \mu \mathrm{m}$, $\mathrm{CZ}=4.45 \mu \mathrm{m})$ (Tellinidae) and Tellina tenuis $(\mathrm{THL}=$ $104.97 \mu \mathrm{m}, 5.24 \mu \mathrm{m})$ (Tellinidae) (Cornet \& Soulard 1990b). Those differences in chromosome sizes observed among $M$. donacium and the Veneroida species mentioned above may be related with interspecific variations in nuclear DNA content (2Cvalue). Nevertheless, although $D$. trunculus and $M$. balthica have longer chromosome size and high 2Cvalues of $3.19 \mathrm{pg}$ and $4.6 \mathrm{pg}$, respectively (Méndez et al. 2001), the expected positive co-relation between both variable is not evident. At present, $2 \mathrm{C}$-values 
for 21 Veneroida species with 38 chromosomes have been described and vary in a wide range from $2.2 \mathrm{pg}$ to 4.6 pg (Méndez et al. 2001, Thiriot-Quiévreux 2002). In the future to much remain to be done on descriptive and molecular cytogenetics in Chilean taxa of Mesodesmatidae including $M$. donacium and $E$. producta. Besides, the nuclear DNA content is also necessary to estimate for both species.

\section{BIBLIOGRAPHY}

Brown, D. \& R. Guerra. 1979. Estados en el ciclo estacional de la gónada de macha, Mesodesma donacium (Lamarck, 1818) en la Bahía de Guanaqueros. Archivos de Biología y Medicina Experimental, 12(4): 500

Cornet, M. \& C. Soulard. 1990a. Chromosome number and karyotype of Donax trunculus (Mollusca, Bivalvia, Tallinacea). Genética, 82(2): 93-97.

Cornet, M. \& C. Soulard. 1990b. Karyometric analysis of two species of family Tellinidae: Macoma balthica (L.) and Tellina tenuis Da Costa (Mollusca, Bivalvia, Tallinacea). Cytobios, 64: 93-101.

Fuentes, I. 1988. Desarrollo y morfología externa comparada de larvas y post larvas de Mesodesma donacium y Mulina sp. (Bivalvia, Mactracea) cultivadas en laboratorio. Tesis para optar al grado de Licenciado en Ciencias del Mar. Universidad Católica del Norte, Coquimbo, Chile.

J ARA-SEGUEL, P. 2007. Avances en estudios cromosómicos de moluscos acuáticos chilenos. Boletín del Museo Nacional de Historia Natural, Chile. 56: 53-61.

Joo, R. \& E. Dupré. 2002. Efecto de diferentes crioprotectores sobre la motilidad spermática de la macha Mesodesma donacium (Mollusca, Bivalvia). Investigaciones Marinas 30(2): 75-79.

Levan, A., K. Fredga \&A. Sandberg. 1964. Nomenclature forcentromeric position on chromosomes. Hereditas, 52: 201-220.

MÉndez, J., A. Insúa \& J. LóPez-PIÑón. 2001. Caracterización citogenética en moluscos bivalvos. pp. 15-48. En:
Méndez-Felpeto (ed.), Los moluscos bivalvos: Aspectos citogenéticos, moleculares y aplicados. Universidad de La Coruña. Xaneiro.

Navarrete, M. H., E. Secadas \& S. M artin. 1983. Análisis citofotométrico de las condiciones óptimas de la tinción Feulgen. Morfología Normal y Patológica, Sección A, 7(2): 239-247.

Ortiz, M. \& W. Stotz. 1996. Distribución de juveniles recientemente asentados de Mesodesma donacium (Lamarck, 1818) (Mollusca: Bivalvia: Mesodesmatidae) en tres bahías de la cuarta región: Variables físicas y químicas que le caracterizan. Biología Pesquera 25: 27-40.

Ortiz, M. \& W. Stotz. 2003. Preliminary estimation of optimal sample size for assessing the recruitment of Mesodesma donacium (Lamarck, 1818) of beaches of central-north Chile: Application of the power analysis. Ciencias Marinas 29(3): 371-375.

Osorio, C., 1979. Moluscos bivalvos de importancia económica en Chile. Biología Pesquera (Chile), 11: 3-47.

Osorio, C. \& N. BAHAMONDE. 1968. Los moluscos bivalvos en las pesquerías nacionales chilenas. Biología Pesquera (Chile), 3: 69-128.

Osorio, C. \& N. Bahamonde. 1970. Lista preliminar de Lamelibranquios de Chile. Boletín del Museo de Historia Natural (Chile), 31: 12-25.

Peredo, S., E. Parada \& I. Valdebenito. 1987.Gametogenesis and reproductive cycle of the surf clam Mesodesma donacium (Lamarck, 1818) (Mollusca: Mesodeamatidae) at Queule Beach, southern Chile. The Veliger 30(1): 55-68.

Spotorno, A., 1985. Conceptos y métodos en cariología descriptiva y comparada. En El núcleo, los cromosomas y la evolución (ed. R. FernándezDononso), pp. 135-163. UNESCO.

Thiriot-Quiévreux, C. 2002. Review of the literature on bivalve cytogenetics in the last ten years. Cahiers de Biologie Marine 43: 17-26.

Urriola, N. \& E. von Brand. 2003. Análisis genético poblacional de Mesodesma donacium. Resumen $32^{\circ}$ Congreso Argentino de Genética, IV Jornadas Chileno-Argentinas de Genética, $36^{\circ}$ Reunión Anual Sociedad de Genética de Chile, p. 38. 